BIODIK: Jurnal IImiah Pendidikan Biologi
ISSN 2580-0922 (online), ISSN 2460-2612 (print)
Volume 6, Nomor 03, Tahun 2020, Hal. 372-383
Available online at:
https://online-journal.unja.ac.id/biodik

Research Article

open 2 ACcess

\title{
Analisis dan Rekontruksi Komponen Lembar Kerja Peserta Didik Pada Praktikum Tulang
}

\section{(Analysis and Reconstruction of the Components of Student Worksheets on Bone Practicum)}

\author{
Fitriani Nurpratiwi Susanto*, Sri Anggraeni, Bambang Supriatno \\ Universitas Pendidikan Indonesia
}

Jl. Dr. Setiabudhi No.229, Cidadap, Isola, Sukasari, Kota Bandung, Jawa Barat 40154-Indonesia

*Corresponding Athors: Lifigatri95@gmail.com

\begin{tabular}{|c|c|}
\hline Informasi Artikel & ABSTRACT \\
\hline $\begin{array}{l}\text { Submit: } 14-06-2020 \\
\text { Diterima: } 30-08-2020 \\
\text { Dipublikasikan: } 14-09-2020\end{array}$ & $\begin{array}{l}\text { Student worksheets as practical guidelines need to pay attention to the quality and } \\
\text { effectiveness. This study aims to provide an overview of the quality of student } \\
\text { worksheets on bone practicum based on the results of analysis, trials and } \\
\text { reconstruction. The research method used is descriptive qualitative, sampling is done } \\
\text { in total sampling by taking } 8 \text { samples Worksheets of students in different curriculum } \\
\text { units, namely KTSP and Curriculum } 2013 \text {. The research instrument used in the form } \\
\text { of rubric completeness components Worksheet for students on conceptual, } \\
\text { procedural aspects, and the knowledge construction and scoring rubric of the Vee } \\
\text { Diagram adapted from Novak \& Gowin (1984). The results showed that in the } \\
\text { conceptual aspect the worksheets of the students analyzed did not yet have } \\
\text { relevance between the content and the demands of the curriculum and the cognitive } \\
\text { level achieved was not appropriate for the cognitive level of high school students. } \\
\text { From a procedural point of view, most of the objectives of the student worksheets are } \\
\text { not yet relevant to the work steps and cannot produce facts fom the object of } \\
\text { observation. While in terms of knowledge construction, all students' Worksheets do } \\
\text { not have a complete Vee Diagram component because they get a zero score (0), } \\
\text { especially in the object / event component so they cannot form knowledge claims. } \\
\text { Based on the problems that have been found, a student worksheet is reconstructed } \\
\text { by paying attention to the conceptual, procedural, and knowledge construction } \\
\text { aspects. } \\
\text { Kevwordc. Practicum Activities Students' worksheets Vee dianrams hones }\end{array}$ \\
\hline Penerbit & ABSTRAK \\
\hline $\begin{array}{l}\text { Program Studi Pendidikan } \\
\text { Biologi, Fakultas Keguruan dan } \\
\text { Ilmu Pendidikan, Universitas } \\
\text { Jambi }\end{array}$ & $\begin{array}{l}\text { Lembar kerja peserta didik sebagai pedoman praktikum perlu memperhatikan } \\
\text { kualitas dan efektifitasnya. Penelitian ini bertujuan untuk memberikan gambaran } \\
\text { kualitas LKPD pada praktikum tulang berdasarkan hasil analisis, uji coba dan } \\
\text { rekonstruksi. Metode penelitian yang digunakan adalah deskriptif kualitatif, } \\
\text { pengambilan sampel dilakukan secara total sampling dengan mengambil } 8 \text { sampel } \\
\text { LKPD pada satuan kurikulum berbeda yaitu KTSP dan Kurikulum 2013. Instrumen } \\
\text { penilitian yang digunakan berupa rubrik kelengkapan komponen LKPD pada aspek } \\
\text { konseptual, prosedural, dan konstruksi pengetahuan dan rubrik penskoran Diagram } \\
\text { Vee yang diadaptasi dari Novak\&Gowin (1984). Hasil penelitian menunjukkan bahwa } \\
\text { pada segi konseptual seluruh LKPD praktikum tulang yang dianalisis belum memiliki } \\
\text { relevansi antara konten dengan tuntutan kurikulum dan tingkat kognitif yang tercapai } \\
\text { tidak sesuai untuk tingkat kognitif peserta didik tingkat SMA. Pada segi prosedural, } \\
\text { sebagian besar tujuan LKPD praktikum tulang belum relevan dengan langkah kerja } \\
\text { serta tidak dapat memunculkan fakta dari objek pengamatan. Sedangkan dari segi } \\
\text { konstruksi pengetahuan, seluruh LKPD praktikum tulang tidak memiliki komponen } \\
\text { Diagram Vee yang lengkap karena mendapatkan skor nol (0), khususnya pada } \\
\text { komponen objek/event sehingga tidak dapat membentuk klaim pengetahuan. } \\
\text { Berdasarkan permasalahan yang telah ditemukan, dilakukan rekonstruksi LKPD }\end{array}$ \\
\hline
\end{tabular}


This BIODIK : Jurnal IImiah Pendidikan Biologi is licensed under a CC BY-NC-SA (Creative Commons Attribution-ShareAlike 4.0 International License)

\section{PENDAHULUAN}

Kemajuan perkembangan ilmu pengetahuan dan teknologi yang cepat saat ini membuat kehidupan manusia memasuki era revolusi industry 4.0. Pada fase ini manusia dalam melakukan aktivitas tidak dapat terlepas dari teknologi dan manusia perlu merevolusi pengetahuan yang dimiliki untuk dapat menciptakan teknologi yang lebih efektif dalam menyelesaikan permasalah yang muncul dalam masyarakat. Oleh karena itu, pendidikan dituntut untuk dapat meluluskan peserta didik yang telah memiliki keterampilan dan sikap individu abad ke-21. Keterampilan abad ke-21 ini dikenal dengan kompetensi 4C, yaitu: keterampilan berpikir kritis (Critical thinking), berpikir kreatif (Creativity), kemampuan komunikasi (Communication), dan kolaborasi (Collaboration) ( Zubaidah, 2018; Amahoroe, 2019).

Keterampilan tersebut bisa didapat oleh peserta didik dari pembelajaran yang terintergrasi dengan hal-hal konkrit yang ada di sekitar lingkungan. Untuk memenuhi tuntutan keterampilan abad ke-21, standar kompetensi lulusan pendidikan pada Kurikulum 2013 yang ditetapkan oleh Kemendikbud dalam Permendikbud Nomor 68 Tahun 2013 yang menyatakan bahwa proses pembelajaran perlu menitikberatkan pada aktivitas peserta didik. Selain itu, banyak peneliti terdahulu telah menyatakan bahwa pengetahuan dapat dipahami dengan lebih baik oleh peserta didik ketika konsep didapat dari aktivitas yang dilakukan peserta didik selama pembelajaran baik melalui kegiatan diskusi maupun berupa penyelidikan dan percobaan melalui praktikum. Sehingga keterampilan dapat terbentuk dari pengalaman nyata dan langsung dirasakan oleh peserta didik selama pembelajaran (Festile, 2017; Sedumedi, 2017; Wahidah, N. S., Supriatno, B., \& Kusumastuti, 2018).

Praktikum telah digunakan untuk berbagai tujuan dalam mengajar. Dalam pembelajaran sains telah digunakan untuk pengembangan keterampilan ilmiah dan konseptual pemahaman (Sedumedi, 2017). Millar (2004) menyatakan bahwa kegiatan praktikum membantu peserta didik dalam menghubungkan dua ranah pengetahuan berupa objek teramati dengan ide. Selain itu, peranan praktikum dalam pembelajaran diperjelas oleh Supriatno (2013) menyatakan bahwa kegiatan praktek memberikan peserta didik kesempatan secara aktif memperoleh data berdasarkan observasi dan atau dapat memanipulasi sehingga terjadi proses kontruksi berdasarkan informasi faktual yang dialaminya.

Agar praktikum dapat terlaksana dengan baik dan sistematis, maka kegiatan praktikum perlu memiliki pedoman yang dapat mengarahkan peserta didik untuk mengkontruksi pengetahuan berdasarkan fenomena atau fakta yang terjadi. 
Pedoman praktikum yang biasa digunakan umumnya mengacu pada Desain Kegiatan Laboratorium (DKL) yang diwujudkan dalam bentuk Lembar kerja peserta didik (LKPD) (Putri, Azza Nuzullah., Anggraeni, S., 2016; Wahidah, N. S., Supriatno, B., \& Kusumastuti, 2018). Lembar kerja peserta didik merupakan lembaran tugas peserta didik yang berisikan petunjuk dalam pelaksanaan kegiatan praktikum. Pengamatan terhadap objek perlu melibatkan semua alat indera pada manusia (Prastowo, 2012; Rahmawati, 2014).

Menurut Rustaman \& Wulan (2007) LKPD sebagai petunjuk dalam pelaksanaan kegiatan laboratorium yang baik hendaknya memiliki beberapa aspek, seperti: 1) tujuan kegiatan, 2) dasar teori, 3) ketersediaan alat dan bahan, 4) prosedur kerja, 5) cara perangkaian alat, 6) interpretasi data hasil pengamatan, 7) analisis data, serta 8) simpulan dari kegiatan praktikum. Sejalan dengan pendapat tersebut, Rahmawati (2014) menjelaskan untuk membentuk dan meningkatkan kemampuan berpikir kritis dan kreatif peserta didik agar sesuai dengan tuntutan kurikulum 2013 perlu adanya proses intepretasi data dan analisis data yang mampu membentuk sebuah simpulan berupa pengetahuan yang terkontruksi berdasarkan hasil pelaksanaan praktikum.

Namun, kenyataannya kualitas LKPD yang sering digunakan di sekolahsekolah sebagai pedoman praktikum jauh dari kata layak dan memiliki permasalahan. Permasalahan ini berdasarkan beberapa hasil studi lapangan yang dilakukan oleh beberapa ahli sebelumnya. Permasalahan yang ditemukan adalah ketidakjelasan dan ketidaksesuaian tujuan praktikum dengan langkah kerja maupun tuntutan Kompetensi Dasar, sehingga fakta yang muncul dari objek pengamatan tidak sesuai dan tidak dapat mencapai tujuan praktikum. Selain itu, tidak jarang fakta yang muncul tidak sesuai dengan konsep, prinsip, dan teori yang dibahas pada materi tersebut. Hal ini dapat mempengaruhi penarikan kesimpulan yang dilakukan oleh peserta didik (Supriatno, 2007; Laelasari, 2018). Permasalahan lain yang muncul dikemukakan oleh Wahidah (2018), hasil penelitiannya menemukan bahwa LKPD yang dianalisis masih terdapat kesalahan prosedur dan tidak terstruktur. Hasil analisis kemampuan kontruksi pengetahuan menggunakan komponen diagram Vee umumnya belum mencapai skor maksimal, sehingga LKPD belum mampu untuk menghasilkan kontruksi pengetahuan. Selain itu, tingkat kognitif yang dituntut dalam LKPD umumnya didominasi prosedural C3 yang lebih sesuai dengan tuntutan Kompetensi Dasar SMP, tetapi tidak sesuai dengan tuntutan Kompetensi Dasar SMA.

Berdasarkan pernyataan-pernyataan yang telah dikemukakan sebelumnya, maka diperlukan LKPD yang dapat membuat peserta didik mengkontruksi pengetahuannya dari praktikum yang telah dilakukan. LKPD praktikum tulang menjadi salah satu praktikum Biologi yang sering dilakukan di jenjang SMP dan SMA. Hal ini dikarenakan alat dan bahan yang diperlukan dalam praktikum cukup mudah didapatkan tanpa perlu ketersediaan alat laboratorium yang lengkap. Oleh karena itu, dalam artikel ini akan dilakukan analisis kelayakan LKPD praktikum tulang dalam aspek konseptual (kesesuaian dengan kompetensi dasar), aspek prosedural 
(kemudahan dan kejelasan langkah kerja), serta kemampuan hasil pengamatan dalam aspek mengkontruksi pengetahuan.

\section{METODE PENELITIAN}

Metode penelitian yang digunakan adalah deskriptif kualitatif yang bertujuan untuk memberikan gambaran fenomena yang ditemukan secara mendalam dan jelas. Penelitian ini menganalisis sejumlah LKPD praktikum SMA kelas XI konsep tulang yang terdapat dalam buku paket, LKPD internal, dan LKPD yang diterbitkan berdasarkan aspek konseptual, prosedural, dan kontruksi pengetahuan. Teknik sampling yang digunakan adalah total sampling sebanyak 8 LKPD. Sampel LKPD terdiri dari 6 LKPD yang disusun berdasarkan Kurikulum 2013 dan 2 LKPD yang disusun berdasarkan KTSP. Intrumen yang digunakan dalam penelitian ini adalah rubrik kelengkapan komponen LKPD untuk aspek konseptual, prosedural, dan kontruksi pengetahuan serta rubrik penskoran komponen LKPD menggunakan Diagram Vee yang dikembangkan oleh Novak \& Gowin (1984) bertujuan untuk mengukur kualitas LKPD dalam proses pembentukan pengetahuan melalui praktikum. Penelitian dilaksanakan melalui tiga tahap yang dinamakan tahapan ANCOR (Analisis, Coba, dan Rekonstruksi) yang dikembangkan oleh Supriatno (2013).

Langkah pertama melaksanakan analisis terhadap 8 LKPD praktikum tulang. Tahap analisis dilakukan untuk mengetahui relevansi LKPD dengan tuntutan kurikulum yang digunakan baik pada KTSP maupun Kurikulum 2013, kesesuain tujuan praktikum dengan konten praktikum, serta kesesuaian penggunaan LKPD dengan tingkat kognitif peserta didik menggunakan rubric kelengkapan komponen LKPD dan rubrik penskoran Diagram Vee dari Novak \& Gowin (1984). Langkah kedua, melaksanakan ujicoba praktikum sesuai langkah kerja pada LKPD tanpa manipulasi. Langkah kerja dimulai dengan pembersihan tulang dari sisa daging, lalu merendam tulang dalam larutan $\mathrm{HCl}$ dengan konsentrasi sesuai yang tertera dalam LKPD, dan selanjutnya mencatat hasil praktikum dalam tabel pengamatan berupa fakta yang terjadi pada objek pengamatan. Langkah ketiga, melakukan rekonstruksi LKPD dengan memperbaiki permasalahan yang ditemukan dari hasil analisis dan uji coba pada aspek konseptual yang berkaitan dengan relevansi kompetensi dasar dan kurikulum yang berlaku, aspek prosedural yang berkaitan dengan prosedur praktikum, serta aspek konstruksi pengetahuan melalui pertanyaan dalam LKPD yang berhubungan dengan fakta dan dapat mengarahkan dalam membentuk konsep, prinsip, dan teori yang benar.

\section{HASIL DAN PEMBAHASAN}

Data hasil analisis kedelapan LKPD pada aspek konseptual meliputi kesesuaian tingkat kognitif, kesesuaian tujuan dan langkah kerja, kesesuaian tujuan dan kegiatan, kesesuaian kompetensi dan kesesuaian konten dapat dilihat pada Gambar 1. 


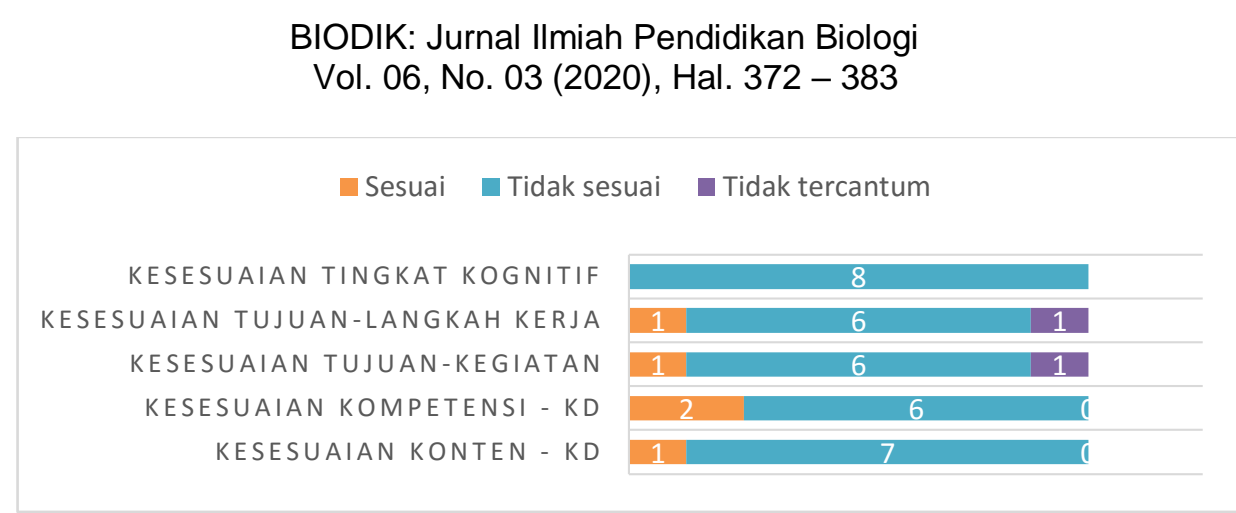

Gambar 1. Bagan Hasil Analisis Aspek Konseptual LKPD

Hasil temuan dari analisis kedelapan LKPD praktikum tulang menunjukkan setiap indikator kesesuaian konseptual LKPD terhadap Kompetensi Dasar baik pada kurikulum 2013 maupun KTSP tidak terpenuhi. Berdasarkan kesesuaian konten dengan Kompetensi Dasar dan tujuan praktikum, dari 6 LKPD kurikulum 2013 isi konten praktikum tidak sesuai dengan ketentuan Kompetensi Dasar di kurikulum 2013 karena didalam konten tidak ada keterkaitan antara penyusun tulang dengan bioproses atau gangguan pada tulang. Sedangkan dari kedua LKPD pada KTSP hanya satu LKPD yang kontennya berisi hubungan antara zat penyusun tulang dengan gangguan fungsi pada tulang. Tujuan praktikum yang terdapat pada 6 LKPD kebanyakan tidak sesuai dengan langkah kerja yang dilakukan. Pada sebagian besar tujuan LKPD praktikum yang dilakukan untuk mengetahui atapun memahami struktur pada tulang, sedangkan pada langkah kerja menunjukkan pengaruh larutan asam terhadap sifat tulang. Sehingga tujuan yang tertera dalam LKPD mengenai gambaran struktur tulang tidak dapat terjawab dan tercapai, karena yang diamati ilah sifat dari tulang. Pada 2 LKPD tujuan praktikum tidak tertera jelas didalam LKPD, sehingga tidak dapat memberikan gambaran praktikum yang akan dilaksanakan dan hasil yang diharapkan.

Dari hasil kesesuaian kompetensi dengan Kompetensi Dasar, hanya LKPD dari KTSP yang kompetensi di dalam LKPD yang sesuai dengan tuntutan Kompetensi Dasar KTSP sedangkan kompetensi dalam LKPD Kurikulum 2013 tidak mampu melatih peserta didik dalam melakukan kegiatan analisis. Hal ini juga ditunjukkan dari tingkat kognitif yang tercapai pada seluruh LKPD baru pada tingkatan C3 prosedural karena hanya menerapkan apa yang diperintahkan dalam LKPD. Hasil analisis ini sesuai dengan yang dikemukakan oleh Supriatno (2013) menemukan sebagian LKPD tidak memiliki tujuan praktikum yang jelas dan terkadang tidak sesuai dengan objek yang diamati. Serupa dengan penemuan tersebut, Laelasari (2018) bahwa $80 \%$ dari LKPD yang dianalisis, tujuan praktikumnya tidak sesuai dengan Kompetensi Dasar dan tidak tercerminkan didalam langkah kerja sehingga hasil praktikum tidak sesuai dengan tujuan praktikum dalam LKPD. Dari hasil kelayakan LKPD penelitian yang dilakukan pada tahun 2013, 2018, dan sampai sekarang menunjukkan bahwa kualitas LKPD hingga saat ini belum mengalami perubahan dan perbaikan. LKPD praktikum yang ada saat ini cenderung merupakan LKPD dari tahun-tahun sebelumnya. 
Kemampuan LKPD dalam mengarahkan praktikan untuk melakukan praktikum dapat dilihat pada tabel 1.

Tabel 1. Hasil Analisis Aspek Prosedural Pada LKPD

\begin{tabular}{|c|c|c|c|c|c|}
\hline & \multirow{3}{*}{ Parameter } & \multicolumn{4}{|c|}{ Jumlah } \\
\hline & & \multicolumn{2}{|c|}{$\begin{array}{l}\text { LKPD Kurikulum } \\
2013\end{array}$} & \multicolumn{2}{|c|}{ LKPD KTSP } \\
\hline & & $\mathrm{Ya}$ & Tidak & $\mathrm{Ya}$ & Tidak \\
\hline 1 & Kemudahan tersediaan alat di Sekolah & 6 & - & 2 & - \\
\hline 2 & Kemudahan ketersediaan bahan praktikum & 6 & - & 2 & - \\
\hline 3 & Langkah-langkahnya terstruktur & 1 & 5 & - & 2 \\
\hline 4 & Setiap langkah dapat dieksekusi tanpa kesulitan & - & 6 & - & 2 \\
\hline 5 & Objek/fenomenanya muncul & - & 6 & 1 & 1 \\
\hline 6 & Objek/fenomena mudah diamati & - & 6 & 1 & 1 \\
\hline 7 & Ketersediaan perekaman objek/fenomena & 3 & 3 & - & 2 \\
\hline 8 & Objek fenomena relevan dengan judul/tujuan & - & 6 & - & 2 \\
\hline 9 & Kesesuaian waktu pelaksanaan praktikum & - & 6 & 1 & 1 \\
\hline 10 & Petunjuk safety lab & 3 & 3 & - & 2 \\
\hline
\end{tabular}

Berdasarkan hasil analisis pada aspek prosedural, ditemukan bahwa alat dan bahan pada ke delapan LKPD yang dibutuhkan dalam praktikum bisa didapatkan dengan mudah pada standar laboratorium di Sekolah. Namun, permasalahan terjadi saat pelaksanaan uji coba praktikum sesuai langkah kerja yang tertera pada setiap LKPD dan proses perekaman data. Sebanyak 7 dari 8 LKPD yang memiliki langkah kerja yang tidak terstruktur sehingga banyak terjadi kebingungan dalam melaksanakan praktikum dan waktu yang diperlukan dalam pelaksanaan praktikum tidak sesuai mengakibatkan objek/ fenomena tidak muncul atau tidak menghasilkan perbedaan yang signifikan antara tulang yang tidak direndam larutan $\mathrm{HCl}$ dengan tulang yang telah direndam dengan $\mathrm{HCl}$ selama 1 jam. Ketidakmunculan objek praktikum dapat dikarenakan kurangnya waktu dalam perendaman. Namun, langkah kerja pada satu LKPD KTSP mengintruksikan perendaman tulang dilakukan lebih dari 1 hari memunculkan objek/fenomena berupa tulang menjadi berwarna gelap dan sangat mudah ditekukkan tanpa tulang menjadi patah. Jika mengikuti hasil dari objek praktikum tersebut, tujuan praktikum yang tertera pada LKPD tidak sesuai dengan objek praktikum yang muncul. Pada kelima LKPD memiliki tujuan praktikum berupa pengamatan struktur tulang yang artinya seharusnya objek praktikum yang terbentuk berupa susunan atau bangun dari tulang, tetapi berdasarkan objek praktikum yang terbentuk adalah sifat tulang yang dipengaruhi oleh larutan asam.

Jika ingin mencapai tujuan tersebut, perlu adanya langkah kerja pembuatan preparat dari tulang yang telah direndam larutan asam, sehingga praktikan dapat membandingkan preparat jaringan struktur tulang normal dengan preparat jaringan struktur tulang yang telah direndam larutan asam dengan menggunakan mikroskop. Hanya saja, pembuatan preparat struktur tulang memerlukan alat khusus dan keterampilan tinggi sehingga sulit dan tidak tepat untuk diterapkan pada peserta didik tingkat SMA. Selain itu, dari kedelapan LKPD hanya 3 LKPD yang memiliki perekaman data berbentuk tabel dan petunjuk safety lab. Hanya saja, tabel yang ada tidak memiliki petunjuk pengisian tabel dan petunjuk safety yang ada tidak memenuhi 
standar safety lab karena hanya meminta praktikan menggunakan sarung tangan dalam melaksanakan praktikum.

Permasalah-permasalah yang ditemukan tersebut sesuai dengan hasil yang telah dikemukakan oleh Rasyida (2010) bahwa 25\% proses praktikum tidak mengacu pada tujuan karena tidak dapat memunculkan fenomena yang sesuai mengakibatkan tujuan tidak tercapai. Serupa dengan permasalahan tersebut, Supriatno (2013) menjelaskan fakta yang muncul tidak sesuai dengan tujuan praktikum maupun materi yang dipelajari dan keberadaan perekam data berupa catatan sangat penting karena dapat mempengaruhi penarikan kesimpulan yang dilakukan oleh peserta didik.

Tabel 2. Analisis Keberadaan Komponen Diagram Vee

\begin{tabular}{|c|c|c|c|c|c|c|}
\hline \multirow{2}{*}{$\begin{array}{l}\text { Kode } \\
\text { LKPD }\end{array}$} & \multicolumn{5}{|c|}{ Komponen Diagram Vee } & \multirow{2}{*}{$\begin{array}{l}\text { Total } \\
\text { Skor }\end{array}$} \\
\hline & $\begin{array}{c}\text { Pertanyaan } \\
\text { fokus }\end{array}$ & $\begin{array}{c}\text { Objek/ } \\
\text { peristiwa }\end{array}$ & $\begin{array}{c}\text { Konsep/prinsip/ } \\
\text { teori }\end{array}$ & $\begin{array}{c}\text { Catatan/ } \\
\text { transformasi }\end{array}$ & $\begin{array}{c}\text { Klaim } \\
\text { pengetahuan }\end{array}$ & \\
\hline \multicolumn{7}{|c|}{ Kurikulum 2013} \\
\hline LKPD 1 & 1 & 0 & 2 & 2 & 1 & 6 \\
\hline LKPD 2 & 1 & 0 & 1 & 1 & 0 & 3 \\
\hline LKPD 3 & 1 & 0 & 1 & 1 & 0 & 3 \\
\hline LKPD 4 & 2 & 0 & 0 & 2 & 1 & 5 \\
\hline LKPD 5 & 1 & 0 & 1 & 1 & 2 & 5 \\
\hline LKPD 6 & 2 & 0 & 0 & 2 & 1 & 5 \\
\hline \multicolumn{7}{|l|}{ KTSP } \\
\hline LKPD 7 & 2 & 2 & 1 & 1 & 1 & 7 \\
\hline LKPD 8 & 1 & 0 & 0 & 0 & 0 & 1 \\
\hline
\end{tabular}

Hasil temuan komponen diagram Vee pada seluruh LKPD (Tabel 2) menunjukkan hanya dua LKPD yang memiliki seluruh komponen diagram Vee, sedangkan ke enam LKPD umumnya yang muncul hanya komponen pertanyaan focus, sedangkan komponen lainnya seperti objek/peristiwa, Konsep/prinsip/teori, catatan/transformasi, dan klaim pengetahuan belum muncul. Hal ini disebabkan karena tidak munculnya objek/peristiwa setelah melakukan praktikum, sehingga mempengaruhi konsep/prinsip/teori yang muncul dan klaim pengetahun yang terbentuk. Sedangkan dalam pencatatan terdapat intruksi untuk mencatat hasil pengamatan, pada 3 LKPD sudah tersedia tabel pencatatan tetapi pada LKPD sisanya tidak tersedia tabel sehingga peserta didik perlu membuat catatan sendiri.

Berdasarkan hasil penskoran setiap komponen diagram Vee (Tabel 2) menunjukkan skor yang di dapat pada setiap komponen masih sangat rendah. Perolehan skor pertanyaan focus menunjukkan skor dibawah ideal (skor 1) artinya pertanyaan focus dapat diidentifikasi tetapi tidak mendukung pada objek/ peristiwa utama yang terjadi. Untuk objek/peristiwa, rata-raya memperoleh skor 0 yang artinya tidak ada objek/ peristiwa yang dapat di identifikasi. Hal ini berhubungan dengan hasil uji coba LKPD yang tidak mampu menunjukkan objek/peristiwa setelah melakukan praktikum. Ketidakmunculan objek praktikum sangat mempengaruhi nilai dari komponen konsep/teori/prinsip, transformasi dan klaim pengetahuan. Menurut Supriatno (2013), menjelaskan bila objek yang di observasi tidak dapat dipahami oleh peserta didik maka bentuk catatan maupun transformasinya akan 
mempelihatkan konsep yang tidak tepat dan prinsip yang terbentuk salah yang akhirnya mengakibatkan klaim pengetahuan yang terbentukpun salah.

Adapun terdapat beberapa LKPD yang memiliki skor klaim pengetahuan bukan berasal dari objek/peristiwa yang muncul dalam praktikum, melainkan hasil jawaban dari pertanyaan-pertanyaan yang bersifat konseptual dalam LKPD yang dapat dijawab tanpa melalui praktikum. Hal ini tidak sesuai (Prastowo, 2012; Rahmawati, 2014) dengan peranan pertanyaan bahwa dalam LKPD perlu memiliki pertanyaan-pertanyaan yang mendukung kegiatan pengamatan dalam pemahaman materi. Ketidakmunculan objek/ peristiwa menyebabkan komponen diagram Vee tidak muncul atau memiliki skor rendah. Tidak lengkapnya komponen diagram Vee dapa setiap LKPD menandakan bahwa LKPD tidak menunjang dalam proses kontruksi pengetahuan (Wahidah, N. S., Supriatno, B., \& Kusumastuti, 2018). Sehingga praktikum tulang yang dilaksanakan tidak memberikan dampak terhadap peningkatan pengetahuan peserta didik.

\section{Hasil Rekonstruksi LKPD Tulang}

I. Judul : Pentingnya kalsium pada tulang

II. Panduan Keselamatan :

Lakukan percobaan ini dengan disiplin, teliti, dan bertanggung jawab. Terapkan prinsip keselamatan kerja dengan menggunakan jas lab, masker, dan sarung tangan karet. Hindari mencium bau larutan asam dari jarak dekat dan tetesan larutan asam pada kulit.

III. Kompetensi Dasar :

3.5 Menganalisis hubungan antara struktur jaringan penyusun organ pada sistem gerak dalam kaitannya dengan bioproses dan gangguan fungsi yang dapat terjadi pada sistem gerak manusia.

IV. Tujuan :

- Mengukur jumlah larutan $\mathrm{HCl}$ yang digunakan secara tepat.

- Mengamati pengaruh larutan $\mathrm{HCl}$ pada sifat tulang keras.

- Mengidentifikasi peran kalsium terhadap sifat tulang.

- Menganalisis hubungan antara penurunan jumlah kalsium dengan tingkat kelenturan tulang dan akibatnya pada fungsi tulang.

V. Dasar Teori

Tulang terbuat dari kalsium karbonat dan bahan lunak yang disebut kolagen. Kalsium (mineral dalam kalsium karbonat) dibutuhkan untuk membuat tulang kita kuat. Namun, seberapa kuat mereka tergantung pada seberapa banyak mineral kalsium karbonat yang dikandungnya. Semakin banyak kalsium yang bisa terakumulasi selama masa pertumbuhan, semakin kecil kemungkinan mereka untuk mengalami masalah tulang yang serius di masa depan. Tulang kehilangan kalsium dari waktu ke waktu, sehingga kalsium harus diisi kembali setiap hari. Kadar kalsium yang rendah pada anak-anak secara konsisten dapat menyebabkan masalah kesehatan, termasuk meningkatnya kemungkinan patah tulang, gigi dan gusi yang tidak sehat, dan rakhitis. Sebagai orang dewasa, kadar yang rendah ini dapat menyebabkan osteoporosis, suatu kondisi menyakitkan yang disebabkan oleh penurunan kepadatan tulang yang sering menyebabkan pinggul patah dan patah tulang lainnya pada orang tua.

Pada kegiatan ini akan digunakan larutan asam berupa larutan $\mathrm{HCl}$ merupakan cairan kimia yang berbau menyengat dan bersifat korosif. Larutan $\mathrm{HCl}$ juga merupakan komponen utama dalam asam lambung. Asam klorida ( $\mathrm{HCl})$ memiliki kecenderungan untuk melarutkan unsur - unsur seperti kalsium (Ca) dengan mengikuti reaksi: $\mathrm{HCl}+\mathrm{Ca}-->\mathrm{CaCl}_{2}+\mathrm{H}_{2}$. Tapi jangan khawatir, asam yang ditemukan dalam beberapa makanan dan minuman tidak akan menghancurkan tulang Anda. 
VI. Alat dan Bahan

Alat:

1) Cawan petri (1)

2) Beaker glass $500 \mathrm{~mL}(1)$

3) Sarung tangan lateks

4) Pinset (1)

5) Silet/Cutter (1)

6) Stopwatch

\section{Bahan:}

1) Tulang sayap ayam segar yang memiliki bentuk dan ukuran sama (3)

2) Larutan $\mathrm{HCl} 20 \%(100 \mathrm{~mL})$

\section{Cara Kerja}

1. Bersihkan ke empat tulang ayam dari sisa-sisa daging yang menempel menggunakan silet.

2. Masukkan tiga tulang yang telah di bersihkan ke dalam beaker glass. Sedangkan tulang ayam lainnya di simpan dalam cawan petri.

3. Siapkan larutan $\mathrm{HCl} 20 \%$ sebanyak $100 \mathrm{~mL}$ menggunakan gelas ukur.

4. Tuangkan larutan $\mathrm{HCl} 20 \%$ pada gelas ukur kedalam beaker glass berisi tulang.

5. Rendam tulang dengan larutan $\mathrm{HCl}$ selama 20 menit, 45 menit, dan 60 menit.

6. Angkat satu persatu tulang dari dalam larutan setelah perendaman 20 menit, 45 menit, dan 60 menit dengan hati-hati menggunakan pinset. Lalu bilas dengan air bersih dan setelahnya di keringkan menggunakan tissue.

7. Amati keadaan tulang yang tidak direndam larutan $\mathrm{HCl}$ dengan tulang yang telah direndam larutan $\mathrm{HCl}$ dengan lama perendaman berbeda.

8. Buatlah perbandingan hasil pengamatan kedua jenis tulang tersebut.

VIII. Hasil Pengamatan

Tabel pengamatan

\begin{tabular}{|l|l|c|c|c|c|c|c|c|c|c|}
\hline No. & Sasaran & \multirow{2}{*}{$\begin{array}{c}\text { Tidak } \\
\text { Pengamatan }\end{array}$} & \multicolumn{4}{|c|}{ Setelah direndam air } & \multicolumn{3}{|c|}{ Setelah direndam dengan HCl } \\
\cline { 5 - 10 } & & $\begin{array}{c}30 \\
\text { men }\end{array}$ & $\begin{array}{c}60 \\
\text { menit }\end{array}$ & $\begin{array}{c}90 \\
\text { menit }\end{array}$ & $\begin{array}{c}120 \\
\text { menit }\end{array}$ & $\begin{array}{c}30 \\
\text { menit }\end{array}$ & $\begin{array}{c}60 \\
\text { menit }\end{array}$ & $\begin{array}{c}90 \\
\text { menit }\end{array}$ & $\begin{array}{c}120 \\
\text { menit }\end{array}$ \\
\hline 1 & $\begin{array}{l}\text { Tingkat } \\
\text { kelenturan }\end{array}$ & & & & & & & & & \\
\hline 2 & $\begin{array}{l}\text { Warna } \\
\text { tulang }\end{array}$ & & & & & & & & & \\
\hline
\end{tabular}

\section{Kriteria:}

Tingkat kelenturan tulang:

+++ : sangat lentur

++ : lentur

$+\quad$ : kaku

$+\quad$ : sangat kaku

\section{Pertanyaan}

1. Berdasarkan pengamatan yang telah dilakukan. Apakah terlihat ada perbedaan sifat antara tulang yang tidak di rendam dengan tulang yang telah direndam dalam air, dan tulang yang telah direndam dalam larutan $\mathrm{HCl} 20 \%$ ?

2. Apa peranan air dalam proses perendaman tulang?

3. Apa peranan larutan $\mathrm{HCl}$ dalam percobaan?

4. Jelaskan pengaruh perendaman tulang dengan menggunakan larutan $\mathrm{HCl} 20 \%$ !

5. Berdasarkan hasil pengamatan, apakah peranan kalsium $(\mathrm{Ca})$ pada tulang?

6. Mengapa lamanya waktu tulang dalam larutan $\mathrm{HCl}$ memengaruhi seberapa banyak kelenturan tulang berubah?

7. Coba kamu tekukkan tulang dengan tekanan yang besar, apa yang terjadi?

8. Tubuh kita memiliki berat yang besar. Apakah menurutmu tulang yang lentur tersebut dapat menopang tubuh? Mengapa demikian?

9. Berdasarkan hasil pengamatan, apa yang terjadi bila kalsium pada tubuh terus terkikis tanpa ada penambahan kalsium dalam tubuh?

10. Kesimpulan apakah yang dapat kalian dapatkan dari hasil praktikum/pengamatan perendaman tulang menggunakan larutan $\mathrm{HCl} 20 \%$ ? 
Berdasarkan permasalah yang ditemukan pada analisis seluruh LKPD sebelumnya, dibuatlah rekonstruksi LKPD dengan menyesuaikan dengan kompetensi dasar, tingkat kognitif, kesesuaian konten dengan judul/tujuan praktikum dan diharapkan layak untuk digunakan. Menurut Rahmawati (2014) menjelaskan bahwa kelayakan LKPD terdiri atas tiga aspek, yaitu materi, kebahasaan, dan penyajian. Kriteria kelayakan materi terdiri atas tiga komponen, yaitu kesesuaian LKPD dengan tujuan pembelajaran, kebenaran konsep, dan penyajian LKPD. Berdasarkan tuntutan kompetensi dasar ada 2 cara untuk merekontruksi LKPD yaitu pertama menyesuaikan prosedur praktikum, hasil pengamatan, dan pertanyaan terhadap tujuan praktikum. Kedua mengubah judul, tujuan praktikum dan hasil pengamatan yang sesuai dengan prosedur praktikum. Dikarenakan struktur tulang berupa penunjukkan komponen susunan bagian dalam tulang dengan cara pengamatan preparat juga terdapat pada pratikum jaringan hewan dan sulit untuk membuat preparat sruktur tulang setelah direndam larutan asam, maka peneliti memutuskan untuk merekontruksi LKPD dengan tujuan mengamati karakteristik sifat tulang keras yang disebabkan oleh salah satu senyawa penyusun tulang yaitu kalsium serta menjelaskan pengaruh larutan asam terhadap sifat tulang. Pada hasil pengamatan ini diharapkan peserta didik memahami peranan kalsium terhadap tulang. Hal tersebut diperjelas oleh dasar teori.

Salah satu permasalahan penting yang ditemukan, yaitu sebagian besar LKPD tidak dapat memunculkan fakta yang benar dari hasil kegiatan praktikum. Kemunculan fakta sangat mempengaruhi dalam mengkonstruksi pengetahuan. Hal ini terjadi karena kurangnya alokasi waktu yang diperlukan dalam melaksanakan praktikum. Alokasi waktu yang digunakan dalam praktikum sama dengan alokasi jam pembelajaran dikelas. Sebagian besar praktikum di sekolah tidak memiliki waktu khusus melainkan memakai jadwal pembelajaran biasa. Namun, bagi sebagian besar praktikum waktu yang tersedia tidak mencukupi dalam menyelesaikan sebuah eksperimen (Yennita et al., 2012; Siburian et al., 2014). Diperjelas oleh Rahmawati (2014) bahwa dalam pelaksanaan praktikum perlu penggunaan alokasi waktu yang dapat menyelesaikan seluruh prosedur praktikum. Oleh karena itu, peneliti mencoba merekonstruksi LKPD dengan mengatur jenis bagian tulang yang digunakan berupa tulang bagian sayap atas dan meningkatkan sedikit konsentrasi larutan $\mathrm{HCl}$ menjadi $20 \%$. Hal ini dikarenakan ketebalan tulang dan konsentrasi larutan $\mathrm{HCl}$ juga mempengaruhi laju reaksi yang terjadi. Namun, fakta yang terbentuk hingga tulang lentur tetap membutuhkan waktu lama dan penggunaan larutan $\mathrm{HCl}$ dengan konsentrasi tinggi berbahaya, sehingga peneliti mengatur alokasi waktu yang dapat dilakukan di sekolah tetapi diluar jam pelajaran dan tanpa harus membawa pulang objek yang diamati.

\section{KESIMPULAN}

Seluruh LKPD praktikum tulang yang telah dianalisis mengandung konten dan tingkat kognitif yang belum sesuai dengan tuntutan kompetensi yang dituntut baik pada KTSP maupun Kurikulum 2013. Hasil uji coba dalam segi prosedural, sebagian 
besar LKPD memiliki tujuan praktikum dan langkah kerja yang tidak relevan. Selain itu, hasil praktikum tidak dapat memunculkan objek yang diharapkan dari tujuan praktikum sehingga LKPD belum mampu dalam mengkontruski konsep, prinsip, dan teori berdasarkan fakta yang terbentuk secara benar. Hal ini didukung hasil penskoran Diagram Vee pada setiap LKPD yang mendapat skor rendah pada setiap komponen dan skor 0 (nol) pada komponen objek/peristiwa karena tidak ada peristiwa yang terjadi selama praktikum. Oleh karena itu, LKPD praktikum tulang masih memerlukan perbaikan baik pada aspek konseptual, prosedural, dan kontruksi pengetahuan agar efektif digunakan dalam pembelajaran dan peserta didik mampu mendapatkan ilmu yang relevan dengan kompetensi yang diharapkan dari kegiatan praktikum.

\section{DAFTAR PUSTAKA}

Amahoroe, R. A. (2019). Pengembangan Desain Praktikum Berbasis Stem Pada Pembelajaran Fermentasi Melalui Pembuatan Tempe Dari Biji Nangka (Artocarpus heterophyllus) Untuk Meningkatkan Literasi Sains Siswa [Universitas Pendidikan Indonesia]. http://repository.upi.edu/40215/

Festile, R.M. (2017). The Influence of Practical Work in the Teaching and Learning of Acids, Bases, and Neutrals in Natural Sciences. University of the Western Cape.

Kemendikbud. (n.d.). Permendikbud Nomor 68 Tahun 2013 Tentang Standar Kompetensi Lulusan Pendidikan Dasar Dan Menengah Pada Kurikulum 2013. https://www.kemdikbud.go.id/kemdikbud/dokumen/Paparan/Paparan Wamendik.pdf

Laelasari, I., \& Supriatno, B. (2018). Analisis komponen penyusun desain kegiatan laboratorium bioteknologi. Jurnal Bioedukatika, 6(2), 84. https://doi.org/10.26555/bioedukatika.v6i2.10592

Millar, R. (2004). The role of practical work in the teaching and learning of science. Wachington DC: National Academy of Sciences.

Novak \& Gowin. (1984). Learning How to Learn. Cambridge University Press.

Prastowo. (2012). Paduan Kreatif Membuat Bahan Ajar Inovatif. Yogyakarta: Diva Press.

Putri, A.N., Anggraeni, S., \& Saefuddin. (2016). Capaian Aspek Hakikat Sains Guru Biologi SMA dan Penerapannya Dalam LKS. Jurnal Pedagogi Hayati, 1(1), 1929. https://doi.org/https://doi.org/10.31629/ph.v1i1.34

Rahmawati, E. (2014). Pengembangan Lembar Kerja Siswa Praktikum Berbasis Konstruktivisme Pada Materi Mollusca. Jurnal Bioedu, 3(1), 398-406.

Rasyida, N. (2010). Analisis Tujuan, Proses dan Pertanyaan Desain Kegiatan Laboratorium Pada Konsep Fotosintesis. [Universitas Pendidikan Indonesia].

Rustaman, A., \& Wulan, A. N. (2007). Kegiatan laboratorium dalam pembelajaran biologi. Universitas Terbuka.

Sedumedi, T.D.T. (2017). Practical work activities as a method of assessing learning in chemistry teaching. Eurasia Journal of Mathematics, Science and 
Technology Education, 13(6), 1765-1784.

https://doi.org/10.12973/eurasia.2017.00697a

Siburian, F., Sinambela, M., \& Septie. (2014). Analisis Pelaksanaan Praktikum Pada Mata Pelajaran. Jurnal Pelita Pendidikan, 5(2), 21-31. https://jurnal.unimed.ac.id/2012/index.php/pelita/article/view/7546

Supriatno, B. (2007). Profil Lembar Kegiatan Biologi Siswa Sekolah Menengah. Proceding Seminar Nasional Jurusan Pendidikan Biologi.

Supriatno, B. (2013). Pengembangan Program Perkuliahan Pengembangan Praktikum Biologi Sekolah Berbasis ANCORB untuk Mengembangkan Kemampuan Merancang dan Mengembangkan Desain Kegiatan Laboratorium. [Universitas Pendidikan Indonesia]. http://repository.upi.edu/3661/

Wahidah, N. S., Supriatno, B., \& Kusumastuti, M. N. (2018). Analisis Struktur dan Kemunculan Tingkat Kognitif pada Desain Kegiatan Laboratorium Materi Fotosintesis. Indonesian Journal of Biology Education, 1(2), 70-76. https://doi.org/https://doi.org/10.17509/aijbe.v1i2.13050

Yennita, Sukmawati, M., \& Zulirfan. (2012). Hambatan Pelaksanaan Praktikum IPA Fisika yang Dihadapi Guru SMP Negeri di Kota Pekanbaru. Jurnal Pendidikan, 3(1), 1-11. https://doi.org/10.1017/CBO9781107415324.004

Zubaidah, S. (2018). Mengenal 4C: Learning And Innovation Skills Untuk Menghadapi Era Revolusi Industri 4.0. 2nd Science Education National Conference, $1-7$. 